\title{
Solidarity as a global bioethical principle: Own reasons for a culture of solidarity from a Protestant perspective

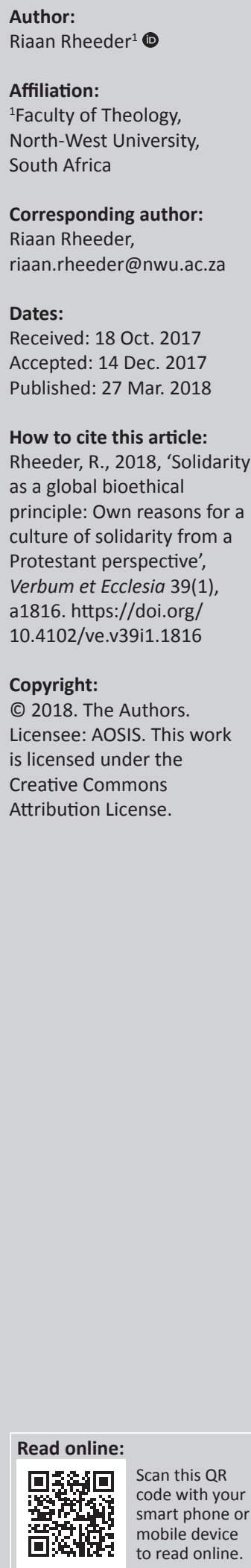

In the development and acceptance of Article 13 of the Universal Declaration of Bioethics and Human Rights (UDBHR), the Protestant faith tradition was not involved in the consultation process (other traditions were indeed consulted). This brings the universality (United Nations Educational, Scientific and Cultural Organization [UNESCO] perspective) as well as the acceptability of the declaration and its principles (civic perspective) into question. To address this issue, it is necessary to involve the Protestant tradition in the discourse by presenting own reasons to support the universal principles in the declaration (theological perspective). In order to achieve the aim, two facets of Article 13 will be studied. In the first place, to present satisfactory own reasons, it is important to investigate and construe beforehand what UNESCO's understanding is of the content of Article 13 of the declaration. In the second place, with sufficient understanding of Article 13, a theological evaluation and grounding will be undertaken. From a broad Protestant perspective, this discourse has shown that solidarity as a shared value can be grounded in a Trinitarian approach. It is clear that Article 13 of the UDBHR can be grounded in a broad Protestant social teaching; therefore, the call for solidarity can be encouraged, wholeheartedly supported and executed.

Intradisciplinary and/or interdisciplinary implications: This study gives attention to global bioethics and human rights, an underdeveloped subject within the field of theological ethics. The study overlaps with political science, philosophy (global ethics) and human rights. It joins the discussion in this discipline and supports the promotion of solidarity within this field, which is very important within the health sector in South Africa.

\section{Introduction}

In 2005, the United Nations Educational, Scientific and Cultural Organization (UNESCO) accepted the universal bioethical principle and human right of Article 13 of the Universal Declaration of Bioethics and Human Rights (hereafter UDBHR or 'declaration') (Rheeder 2017; UNESCO 2005, 2006). The principle is formulated as follows: 'Solidarity among human beings and international cooperation towards that end are to be encouraged' (UNESCO 2006). For the first time in the history of bioethics, it was expected that solidarity should be taken into account in the global bioethical discourse. One of the achievements of the UNESCO declaration was that solidarity, which had previously only been encouraged, gained the status of a universal ethical principle with the declaration. The UDBHR was accepted unanimously by all member states (without any notated dissentient vote, reserve or qualification) (International Bioethics Committee [IBC] 2008:45; Ten Have \& Jean 2009:17). This means the declaration, with its 15 bioethical principles, was the first bioethical political text in the history of bioethics, and it is still the only one to which almost all the governments in the world, including South Africa, committed themselves (UNESCO 2005).

The research problem seen from a UNESCO, civil and theological perspective is indicated by Tham (2014:2-3), a UNESCO bioethicist, saying that during the development process of the declaration, only one short meeting was afforded religions (Islam, Confucianism, Buddhism, Hinduism, Roman Catholicism and Judaism) to make an official contribution to the declaration (Gallagher 2014:135; IBC 2004:2-4; Ten Have \& Jean 2009:31). Tham emphasises that there was no contribution from the Protestant tradition. Ten Have (2016), previous director of the Division of Ethics of Science and Technology at UNESCO, confirms the dilemma:

It is clear that given the short time frame for drafting the declaration (2003-2005), the development of the text and the resulting consensus has been vulnerable to criticism since not all relevant actors could be consulted while others did not feel represented by the experts involved. (p. 102)

To be truly credible and representative, it is unacceptable that the support of only some religions serves as validation for a global bioethics (see also Rheeder 2017). 
From a UNESCO perspective, it is important to make the UDBHR (and Article 13) more representative and thus strengthen the claim to universality. From a civil perspective, it is also important to make the declaration more representative of the religions in a specific state. It has to be kept in mind that according to the 'Foreword', the UDBHR describes itself as 'universal principles based on shared ethical values' (UNESCO 2006) - also known as 'common morality' - that form an independent metatheory. What are shared values? John Rawls (1993), an American political philosopher in the liberal tradition, answers the question as follows (see also Wenar 2017):

Since justification is addressed to others, it proceeds from what is, or can be, held in common; and so we begin from shared fundamental ideas implicit in the public political culture in the hope of developing from them a political conception that can gain free and reasoned agreement in judgment, this agreement being stable in virtue of its gaining the support of an overlapping consensus of reasonable comprehensive doctrines. (pp. 100-101)

Firstly, Rawls (1993:144) acknowledges that pluralism is a permanent historical reality that cannot be ignored. Each reasonable citizen has his or her own view of God and life, right and wrong, and good and bad (reasonable comprehensive doctrines) (see also Rheeder 2017). He is convinced, however, that this is a reasonable pluralism that does not want to enforce values on others, but that it rather strives for shared values. It departs from the viewpoint that diverse ethical traditions share a minimum of ethical values with each other because of consensus that is known as 'overlapping consensus' or 'political conception', according to Rawls (Ten Have 2011:25; Wallace 2009:55-68). The reason for using shared values is that they are not based on any specific philosophy or religion, but flow from the 'political culture', with the special value that supporters of diverse ethical theories can agree with each other about bioethical principles, as is clearly shown by the declaration (see also Gallagher 2014:135; Ten Have 2011:23).

Secondly, the question of legitimacy remains: Why would the global community (also the citizens of a Protestant religious tradition) accept shared bioethical values? According to Rawls (1993:134), diverse ethical traditions or groups can support shared values, but they do it based on different or own reasons: 'In such consensus, the reasonable doctrines endorse the political conceptions, each from its own point of view'. In this way, shared values are confirmed by own moral grounds, and they are experienced not as pressure by others, but as part of the own moral system (see also Rheeder 2017).

Thirdly, Rawls (1993:140-144) is convinced that if citizens cannot present reasons from their own religious or philosophical tradition to support the shared bioethical values, the shared values would not be valid and the social order would disintegrate (Wenar 2017). From another angle, the philosopher Charles Taylor supports the viewpoint of Rawls in his influential work, The politics of recognition (1994). According to Taylor (1994:34), moral (cultural) diversity as a unique human identity is essential to human existence.
When the identity of individuals and groups is consciously denied, ignored or passed over, it leads to alienation and disillusionment. Maggay (2017:1202-1205) states that one of the reasons why universal values in some Asiatic and Arabian countries receive so little respect is 'the lack of a deep enough philosophical basis for human rights in these cultures'. The lack of interest in and the absence of own reasons for endorsing the universal values of the UDBHR are probably the most important reasons why the declaration, according to an in-depth study by Langlois (2013:154), has had no or very little impact on the bioethical community in democratic South Africa. Own reasons from the Protestant tradition will strengthen the civil acceptability of the shared values in the declaration and can make a contribution to the discourse on universal bioethical values in South Africa (see also Rheeder 2017).

The faith community as part of the civil society in a democracy can have a big impact in the area of global bioethics. In this connection, Ten Have (2016:21-22) refers to the example where the Tongan government secretly gave permission to Autogen, an Australian biotechnological company, to collect genetic material of Tongan citizens and, with a view to research, store them in a databank in exchange for annual financial support and royalties (see also Rheeder 2017). When this agreement became known, churches (and pro-democratic groups) broke out in revolt because they were of the opinion that the citizens had given no informed permission for this agreement and that it posed a big threat to their privacy and confidentiality; consequently, the project was abolished in 2001 (Burton 2002:443). This incident is proof that the Christian Church in general and Protestantism in particular can make a substantial contribution to promoting solidarity in the health environment.

This article is meant to be part of the discourse by and with the broad Protestant tradition in order to make the UDBHR more representative, on the one hand, and to present own (theological) reasons for inhibiting possible alienation, strengthening the validity of the declaration and in this way bringing about a bigger impact, on the other hand. The central theoretical statement of this discourse is that sufficient own reasons exist in the broad Protestant theology to accept Article 13 of the UDBHR and therefore to see it as part of the calling of the Christian community (see also Rheeder 2017). What is meant by Protestant? The following statement of Matz (2017) is relevant to social ethics:

For Protestants, Scripture is the ultimate authority for faith, life, and doctrine, and this is no less true in the field of social ethics ... Scripture is foundational for Protestant social ethics ... (see also Pauls \& Hutchinson 2008:431; Van Leeuwen 2014:419-420)

In order to achieve the aim, two facets of Article 13 will be studied. Firstly, to present satisfactory own reasons, it is important to investigate and construe beforehand what UNESCO's understanding is of the content of Article 13 of the declaration. The investigation will focus exclusively on official material by UNESCO and commentators that interpret the declaration with the aim of suggesting a 'UNESCO 
perspective' (Martin 2014:119; Shickle 2014:486). Secondly, with sufficient understanding of Article 13, a theological evaluation and grounding will be undertaken.

To execute the first facet to achieve the aim, the content of Article 13 will now be investigated and construed.

\section{Solidarity as concept}

According to Gunson (2009:242), the UDBHR uses the concept of solidarity in such a wide sense that it does not contribute to understanding it and reconstructing its meaning (cf. also Prainsack \& Buyx 2011:31). I am nevertheless of the opinion that analyses of the declaration itself and of educational material of UNESCO, as well as interpretations of exponents of the declaration, can be used as heuristic tools to construe a probable and workable meaning of solidarity as found in Article 13. This point of departure is in agreement with Article 31 of the Law of Treaties (The Vienna Convention), which states that a credible interpretation of universal principles is possible if the interpretation takes place according to the general guideline that reads:

... interpreted in good faith in accordance with the ordinary meaning to be given to the terms of the Treaty in their context and in the light of its object and purpose. (Kirby 2009:73)

The UNESCO declaration uses the concept 'solidarity' three times (Prainsack \& Buyx 2011:31). Two references to the concept occur in Article 13 ('Solidarity and cooperation'), namely, in the title and in the content, while the third reference is found in the third clause of Article 24 ('International cooperation') (Garrafa 2016:169-170; Khoo 2015:272-273). Article 13 uses the concept of solidarity in the following way: 'Solidarity among human beings and international cooperation towards that end are to be encouraged'. Article 24 offers a little more information in the statement of clause 3 (UNESCO 2006):

States should respect and promote solidarity between and among States, as well as individuals, families, groups and communities, with special regard for those rendered vulnerable by disease or disability or other personal, societal or environmental conditions and those with the most limited resources. (n.p.)

The Bioethics Core Curriculum 1, an official guide that is used in global education in the declaration, presents the following workable definition of the concept solidarity (UNESCO 2008):

Solidarity as moral value: Group oriented responsibility to care for the weaker and more vulnerable members of the community. Real solidarity implies that we take care of vulnerable persons even if it would not be in our interest or even if there is no specific purpose. Human beings share identity as members of the same collectivity and therefore feel a mutual sense of belonging and responsibility. Solidarity in this sense is 'humanitarian solidarity'; it is the expression of an ethics of commitment, a sense of responsibility towards the most vulnerable in society. Not selfinterest but the interest of others motivates cooperation. (p. 45)

From the UDBHR, the Bioethics Core Curriculum 1 (UNESCO 2008) and several scientific analyses of the declaration, a few aspects or features of solidarity can be distinguished.
Scholz (2016:2658), however, is correct when she states that although these aspects can be distinguished from each other because of logical reasons, they cannot be separated from each other.

The first aspect is that the UDBHR connects human dignity to solidarity (Art. 3, UDBHR) with the statement in Article 2(c) (as well as Art. 26, UDBHR), which reads that the aim of the declaration is among others 'to provide a universal framework of principles', with the specific purpose 'to promote respect for human dignity' (UNESCO 2006; see also Revel 2009). Where solidarity is found, expression is given to human dignity, and where these principles or norms are respected, people are treated with human dignity.

The second aspect of solidarity that can be deduced from the UDBHR is the recognition of different ways of existence. According to Articles 13 and 24, three categories of human existence can be distinguished. The first category recognised by the UDBHR is the individual existence and functioning of the human being. The second category of existence, which is indicated by Article 24, is the phenomenon of different smaller collectivities, namely, States, families, groups and communities ('States, as well as individuals, families, groups and communities') (Reichlin 2011:368). In the Bioethics Core Curriculum 1, UNESCO (see the Bioethics Core Curriculum 1 workable definition of the concept solidarity) refers to human beings as 'members of a community'; elsewhere, they are said to 'share identity as members of the same collectivity' (UNESCO Chair in Bioethics, Haifa 2016:104). The third category of existence indicates the one large international community as one universal 'collectivity' (Elungu 2009:212). In the discussion of the relationship between solidarity (Art. 13) and sharing benefits (Art. 15), the IBC (2015) states in their Report of the IBC on the principle of the sharing of benefits, 'All human beings are intimately related in solidum, i.e. as an indivisible whole'. Article 13 refers specifically to solidarity 'among human beings' at international level ('international cooperation'), which indicates a global community.

The third aspect of the concept of solidarity that can be deduced from the wording of Articles 13 and 24 is that solidarity as a social concept is understood as something 'among and between' human beings (Ten Have 2016:216). It is not very clear from Articles 13 and 24 or the rest of the declaration exactly what is meant by 'among and between'. To my mind, the Bioethics Core Curriculum 1 (UNESCO 2008) gives a probable hint how this 'among and between' should be interpreted when it says, 'Human beings share identity as members of the same collectivity and therefore feel a mutual sense of belonging and responsibility'. The UNESCO casebook on bioethics for judges uses the same description saying, 'Human beings share an identity as members of the same collective' (UNESCO Chair in Bioethics, Haifa 2016:104). The key idea here is experiencing or recognising a 'same collectivity' or 'sameness' (also 'similarity'). The concept of 'sameness' is also found in bioethical material outside the UNESCO context (Prainsack \& Buyx 2011:45), for example, in the work of Evers and Klein (2010), but it is not discussed any further here. 
This sameness or similarity can be interpreted in three ways. Firstly, 'same collectivity' ('among and between') indicates a shared human nature. Solidarity means recognising your being human in other people; thus, it relates to the first and third categories of existence (Reichlin 2011:368-369; Ten Have 2016:217; UNESCO 2006). Secondly, 'same collectivity' means that people have or experience shared or the same physical, psychological and cultural characteristics. It could be argued that there is a possibility here of a more 'natural' and homogeneous association when people belong to each other and are closer to each other than when people have no connection with each other. In this way, the families, groups and communities to whom the UDBHR refers can be very homogeneous, because they have shared physical and psychological characteristics that are the same, and thus, a feeling of sameness and similarity is created. Human beings of the same race or gender can experience sameness because of shared characteristics. Another term used here is shared identity (Reichlin 2011:366; Scholz 2016:2654; Ten Have 2016:216). There are different characteristics of sameness that bind people together and create a feeling of bonding, and that are narrower than humankind and the State: language, culture, lifestyle, identification with a specific history and political institutions, sharing an economic situation or religion (Reichlin 2011:366). In these instances, a sense of close and spontaneous solidarity can be very strong. In the context of the previous understanding of solidarity, the concept is judged, thirdly, to be prejudiced. Thus, a father can show preference for solidarity towards his own family because of a certain sameness. Although this description might be true, it is not the whole truth: partiality is not the only description of solidarity because solidarity enables and promotes inclusiveness. Sameness also means shared experiences, aims and interests (IBC 2010:23; Scholz 2016:2654). Thus, 'same collectivity' ('among and between') means people that differ from each other in many ways can recognise or experience a sameness or similarity (cf. also Prainsack \& Buyx 2011:47). Shared experiences, interests and aims can enable people with different and diverse personalities to experience and recognise sameness (Reichlin 2011:366; Ten Have 2016:216). The shared experience of human suffering can lead to the realisation of sameness that develops into solidarity (Ten Have 2016:216). Thus, the experience of an individual or a family that has conquered cancer or is suffering from the same serious disease could lead such an individual or family to experience a sameness with an individual or family in another country or culture and motivate them to support that individual or family (Scholz 2016:2654). Shared aims (causes, in the sense of organisations or ideas that people support or fight for) lead people to recognise sameness. As an example, Ten Have (2016:217) refers to the organisations of homeless people in Mumbai and the Treatment Action Campaign (TAC) in South Africa, which both have elicited global solidarity with regard to specific aims (causes). The organizations of homeless people in Mumbai has brought individuals, groups and non-profit organisations locally and from over the world together with the common goal to provide reasonable housing to vulnerable people.
The TAC has formed local and global networks with a view of promoting basic health care. The fact that solidarity in the UDBHR is directed not only at the national community but also at the global community can bring about a connection between national networks and similar global networks, because they are identifying themselves with a common issue and share common values and objectives with each other (Ten Have 2016:217). These collectivities relate to the second category of existence.

People experiencing and recognising a sameness spontaneously feel and develop a 'sense of belonging' (IBC 2010:23; UNESCO Chair in Bioethics, Haifa 2016:104). They feel closely connected to each other. There is an 'integration or rootedness of each individual member within the group' (IBC 2010:23) in which interaction takes place (Reichlin 2011:366). A rational and emotive aspect is connected with all three of the above forms of recognising sameness. People know what being human comprises and therefore they can have compassion with the other human being in his or her circumstances (Scholz 2016:2658). These are, however, not only spontaneous actions, but according to Scholz (2016:2658), sometimes there is also a 'willingness to acknowledge social bonds with others', especially where no close social bonds exist. The consequence of the idea of sameness is that individuals and collectivities experience and accept a certain responsibility, duty and commitment towards each other (IBC 2015:7; UNESCO Chair in Bioethics, Haifa 2016:104). The point of departure is that the individual, group and humanity are just as much 'our' responsibility as they are 'theirs' (Reichlin 2011:366).

The fourth aspect of solidarity is actively observing (identifying) and becoming aware of human need in the health environment. This observation consists of two aspects (Reichlin 2011:366). Firstly, observation, according to Article 13 (and Article 24), means becoming aware of human vulnerability and need ('with special regard to vulnerability') (Ten Have 2016:217-218). There has to be a certain disposition and sensitivity to human vulnerability. According to Article 24.3, vulnerability and need are caused by illness, a disability and personal, social and environmental factors, as well as limited resources, all of which can be detrimental to human wellness. The special attention for vulnerability is an acknowledgement that only emphasising autonomy in global bioethics is not sufficient to address human problems. Vulnerability means precisely that the autonomy of people is not strong or effective enough to help them and that solidarity with its emphasis on vulnerability indeed wants to help people that cannot help themselves (Scholz 2016:2654-2655). Secondly, regarding observation, it can be deduced from the words in Article 24, '... those rendered vulnerable by ... societal ... conditions ...', that the focus of solidarity is not only on the vulnerable human being, groups or the community but also on protecting and developing any existing good social order, which has an inherent potential vulnerability. According to Ten Have (2016:216), solidarity also wants to prevent the breakdown of good and functional social order. 
The fifth aspect of solidarity is becoming actively involved in alleviating vulnerability. Research by Garrafa (2014:169, 182-183) shows that the concepts of cooperation and solidarity are used together for the first time in a universal principle in the UNESCO declaration. Both Articles 13 and 24 connect solidarity and (international) cooperation, and the specific formulation in Article 13, namely 'international cooperation towards that end', means solidarity and cooperation form a close unity (Elungu 2009:211, 216; Garrafa 2014:169; Ten Have 2016:216, 218). The word 'cooperation' is derived from the Latin co + operare, which means 'working together in achieving a common goal'.

The IBC (2015) says the following about the connection between cooperation and solidarity in the bioethical environment:

In the context of bioethics, solidarity means not only a vertical and episodic intervention, but also genuinely cooperative relationships that contribute to effective improvement of the life of individuals, groups and countries. (p. 7)

Solidarity indicates that vulnerability and need have to be addressed by means of active cooperation. The Bioethics Core Curriculum 1 (UNESCO 2008) refers to this statement and defines solidarity as a cooperative process in which support and care is given to vulnerable human beings (UNESCO Chair in Bioethics, Haifa 2016:104). It concerns help to vulnerable people (Ten Have 2016:217). The concept of cooperation indicates a realisation of interdependency (Scholz 2016:2654), which implies the knowledge that the individual, group or community is sometimes powerless in the presence of greater national and global problems. Tackling the problems together has a better chance of making an impact and bringing about change (Ten Have 2016:217-218). It is again recognised that the emphasis on autonomy in bioethics alone is not sufficiently effective.

However, Garrafa (2014:179-180) is of the opinion that the specific use of the word 'cooperation' does not only refer to charity, altruism and philanthropy but also refers to symmetrical relations and capacity. Solidarity is not merely a 'hand-out' action, but a process during which the givers and receivers of solidarity work together as equals, and equipment and tools are given to people in need to enable them to escape the vulnerable situation in a sustainable way. A 'hand-out' approach actually smothers autonomy, strengthens dependence and increases self-confidence, whereas cooperation effects the opposite outcome (Ten Have 2016:217).

The sixth aspect of solidarity in the UDBHR is that the concept is meant to be health related. Although Articles 13 and 24 do not specify with regard to which specific matters solidarity has to be striven for, some of the other articles in the declaration shed more light on the issue and give practical examples (Garrafa 2014:169). Three points are important here. The IBC of UNESCO discusses Article 14 ('Social responsibility and health') of the UDBHR in a report and emphasises the first point saying, 'First of all, Article 14 should be read in the light of Article 13 on solidarity and co-operation ...'
(IBC 2010:24). According to Reichlin (2011:365, 370), Article 13 forms the foundation and motivation for social responsibility in health care. It means the content of Article 14 regards challenges to people to show solidarity as a priority (Khoo 2015). Article 14.1 reads as follows:

The promotion of health and social development for their people is a central purpose of governments that all sectors of society share. (p. 273)

Article 14.2 states solidarity has to be directed at the promotion of health and social development in such a way that the 'highest attainable standard of health' is achieved. According to Article 14.2 (a-e), the latter is brought about by quality health care, sufficient water and nutrition, favourable life and environmental circumstances, elimination of marginalisation and exclusion, as well as diminishing poverty and illiteracy.

Secondly, in the Report of the IBC on the principle of the sharing of benefits, the following statement is made:

In this perspective, one of the most visible manifestations of the interplay and complementarity between the principles of the Declaration - expressed in Article 26 - is the close relationship between Article 15 and Article 13, which deals with solidarity and cooperation. (IBC 2015:7)

Article 15.1 of the UDBHR, which pertains to the sharing of benefits, reads as follows (UNESCO 2006):

Benefits resulting from any scientific research and its applications should be shared with society as a whole and within the international community, in particular with developing countries. (n.p.)

Benefits according to Article 15.1 (a-g) include health-related matters such as assistance to and recognition of persons that have participated in research, access to quality health care, provision of diagnostic and therapeutic aids, support of health services, access to scientific and technological knowledge and support of capacity-building facilities directed at research. Also, Garrafa (2014:184) is convinced that Article 15 has to be regarded as a normative reference.

Thirdly, Elungu (2009:215), Gunson (2009) and Scholz (2016:2655) are of the opinion that the practical application of every other article (together with Articles 14 and 15) has to be regarded as the application of solidarity. Solidarity has to be promoted with the aim of helping vulnerable people in the health environment with respect to human dignity and human rights (Art. 3), benefit and harm (Art. 4), autonomy and individual responsibility (Art. 5), informed consent (Art. 6 and 7), respect for human vulnerability and personal integrity (Art. 8), privacy and confidentiality (Art. 9), respect for cultural diversity and pluralism (Art. 12), protection of future generations (Art. 16) and the protection of the environment, biosphere and biodiversity (Art. 17).

The seventh aspect of solidarity is that it is an intrinsic value, and therefore, it is 'to be encouraged' (Art. 13), and it has to be respected and promoted (Art. 24). The Bioethics Core Curriculum 1 provides a further perspective on interpreting 
Article 13 and indicates that there are two different views regarding the understanding of solidarity and cooperation (UNESCO 2008:54). Some commentators understand solidarity as an instrumental and other as an intrinsic value. In the first view, solidarity and the decision to work together are based on the expectation of optimal benefits or profits for those that show solidarity. Solidarity and cooperation according to this perspective are primarily based on the own interest of the individual, group, communities or national interests of States (Ten Have 2016:218-219; UNESCO 2008:54). In the second view mentioned, solidarity and cooperation are seen as intrinsic values, and according to the Bioethics Core Curriculum 1 and Ten Have (2016), it is also the view of Article 13. Solidarity and cooperation as intrinsic values are not primarily or even not at all motivated by self-interest, but are mainly concerned with the well-being of the vulnerable human being (UNESCO 2008:54). People showing solidarity and participating in cooperation have no expectations of any benefits and know they may even incur costs (Ten Have 2016:218-219). Ten Have (2016) supports the view of the Bioethics Core Curriculum 1 and summarises it saying:

In real life human beings are disposed to cooperate for other reasons than self-interest. They are 'a cooperative species'; they share common interests and work together because they value ethical behavior for its own sake. (p. 220)

In summary, UNESCO accepts solidarity as a universal principle that has to be encouraged in the health environment, because this human right gives expression to human dignity. Solidarity means that because individuals, families, groups and communities recognise and experience sameness, they will identify vulnerability and engage in active helping to improve primary health and social development. Moreover, they will take care that vulnerable people will share in the fruits of research in the field of health without expecting to receive something in return.

In executing the second facet of this study, namely a theological evaluation and grounding of Article 13 of the UDBHR, the above reconstruction of the meaning of Article 13 will now be viewed from a theological-ethical perspective. In other words, the principle that solidarity and cooperation have to be encouraged in the bioethical environment will be evaluated according to and grounded in theological-ethical principles.

\section{Theological perspective Introduction}

It is not only important to give reasons for the shared values of solidarity and cooperation from UNESCO and civil perspectives, but it is also necessary to indicate own reasons from a theological perspective why these values can be supported. Hollinger (2008:64) argues that, first, in contrast to the theory of shared values, God is the foundation, norm and authority of all ethics. The human rights expert and ethicist in the Protestant tradition, JM Vorster (2015:109) connects the Bible to shared values when he states that the second commandment (Ex 20:4-6) lays down knowledge of and living according to the Bible as a duty (see also Rheeder 2017). He continues saying:

Hiermee word ten diepste 'n belangrike fundering vir Christelike morele handelinge gelê. Uiteindelik bied die geskrewe Woord die beginsels vir die etiek en is dit ook die toetssteen van alle etiese kodes en handelinge. [With this, at the very base, an important foundation for Christian moral actions is laid. Ultimately, the written Word provides the principles of ethics and it is also the touchstone for all ethical codes and acts.] (p. 109)

The Christian testing and grounding (presenting reasons) of shared bioethical values (and individual human rights) is a new development in Protestant ethics and has been introduced by two books, namely Covenantal biomedical ethics for contemporary medicine: An alternative to principles-based ethics by Rusthoven (2014) and The New Testament and bioethics: Theology and basic bioethics principles by Macaleer (2014) (see also Rheeder 2017). It is remarkable that a similar development is also taking place in the Roman Catholic Church and theology (see also Clark 2014:43-44). Macaleer (2014:24-30) clearly shows that up to the publication of his book, no Protestant ethicist has given truly in-depth attention to a theoretical foundation or grounding of modern global bioethical principles. His book deals with the Protestant foundation of the four universal bioethical principles of Beauchamp and Childress (autonomy, beneficence, maleficence and justice) (see also Rheeder 2017). Macaleer (2014:ix-x) summarises the principles as follows:

As outlined by Beauchamp and Childress, these principles are based on what they call the common morality. Thus, the principles have no specific theological foundation; this book attempts to give those principles a Scriptural foundation. (pp. ix-x; see also Rheeder 2016:2)

According to Rusthoven (2014:201-203), Protestant ethics have to 'explore the normativity of the principles of principlism' or shared bioethical values, as these do not flow from a Christian or Protestant life and worldview. 'A Christian ethical approach should start with the main question, and that is the question of the theological foundation for human rights and the responsibilities they impose on man', Vorster (2004:22-24) writes. The same is true of the universal principles of the UDBHR for which no theological foundation exists (see also Rheeder 2017). The philosopher Charles Taylor (2007:702) acknowledges the possibility and desirability of an own Christian foundation of solidarity as universal principle. Secondly, according to Stott, McCloughry and Wyatt (2006), with reference to the aforementioned statement, a theological foundation gives moral authority and power to universal principles (Lorenzen 2009:298). It is also of special value for the Christian, because a Christian foundation forms the religious motivation and impetus for executing a human right as a shared value. A foundation forms part of 'I believe in' (Waldron 2010:233-234) and can help that human rights and universal bioethical principles live in the heart of the Christian (Vorster 2004:24) (see also Rheeder 2017). The theological question is verbalised as follows by Clark (2014): 
However, in the twenty-first century one thing is now clear: a full appreciation of either the Universal Declaration or Catholic social doctrine requires grappling with those foundations and being able to argue why. (p. 43)

The same question is valid for Protestant social ethics: Why is solidarity a Biblical value?

In their discussion of cultural diversity and identity, as well as human rights, Volf (1996:25) and Vorster (2004:80) state the Trinitarian doctrine is a Protestant point of departure in evaluating and grounding ethical issues. Heyns (1982:89-109) summarises this view in a striking way when he points out that the Father is the foundation of creation, the Son is the foundation of recreation and the Spirit is the eschatological foundation of all ethics. Also Charles Taylor (2007:702) relates the motivation for solidarity as global principle to the Trinity (see also Clark 2014:55).

With the doctrine of Trinity as the frame of reference, solidarity as shared value is now discussed, evaluated and founded.

\section{Creation perspective}

Nolan (1976:59) points out that the word 'solidarity' does not occur in the Bible, but that the idea of solidarity is undoubtedly found throughout the Bible. 'The notion of solidarity with the poor, given fullest expression in Christ's life and teaching, is firmly rooted in the Old Testament', MacLaren (1991:489) writes. In her grounding of solidarity (as human right), Clark (2014) states the following:

Using the biblical theology of the imago dei ... and the theology of covenant, I seek to develop a theological anthropology that grounds both human rights and solidarity in our creation in the image and likeness of God. (pp. 6, 56-57; see also Macaleer 2014:107)

Both the concepts of human dignity (human rights) and solidarity, firstly, flow from the fact that the human being is created in the image of God (Gn 1:26-27). To be a bearer of the image of God implies a status and a duty. In this hierarchy of existence, God forms axiomatically the highest form of existence and dignity (Higginson 1995:98), and therefore, he is praised in Revelation 4:11 as 'worthy' (see also Heb 3:3). If God is absolute dignity and the human being bears his image, then the human has derived but definitive human dignity (Mt 6:26; 2 Pt 1:4). Morphew (2015) puts it in a striking way saying, 'If God can become a man, how great can man be?' (see also Clark 2014:57). The human being has the status of human dignity. The fact that the human being or all human beings are created in the image of God is an indication of the equality or 'sameness' of all people regarding human dignity and being a human being (Macaleer 2014:173).

Secondly, the human being is created in the image of the triune God (imago Trinitatis). The intra-Trinity as the multiple existence of God is regarded as a social model or foundation for humanity as persons-in-relations, from which the duty of the human can be deduced (Bridger 1995:352-353; Plantinga, Thompson \& Lundberg 2010:115). The triune God, the Father, Son and Holy Spirit are equal (co-equal) to each other and form a 'sameness' in this way (Rm 9:5; 2 Cor 3:17-18; Mt 28:19; Bridger 1995:352-353; Plantinga et al. 2010:115). From the sameness of the triune God flows a relational and cooperative existence and lifestyle: '... as we are one' (Jn 10:30, 17:21-23). According to John, this unity is a cooperative relationship of love and solidarity, which brings glory (doxa) or dignity into the world of vulnerability (Jn 17:22; Clark 2014:52-57). The prayer of Jesus clearly states that God brings glory to the world in an intra-Trinitarian cooperative relationship of love; likewise, the human as the image of God has the duty to go out and bring glory into the world in a cooperative relation of love, 'so that they may be one, as we are one' (Clark 2014:58).

Thirdly, God does not only exist in a relationship with himself but moves outwards and also stands in a covenant relationship with the human being. The covenantal interaction with the human being must be realised or imitated by the image bearers of God. The decision of God to step into a covenantal relationship with humanity, communities and future generations is in itself a form and proof of solidarity. Covenant means solidarity (Clark 2014:62-63; Hessel 1979:253). God's covenants with Adam and Eve, Noah, Abraham and Moses (also Jesus) are of particular importance in the grounding of solidarity. Childress (2002) also judges that from a Protestant angle, grounding for bioethical principles can be found in the leitmotif of the covenant. He explains it as follows:

Human covenants, such as medicine, can mirror and reflect God's covenants, and such covenants share several features ... Those covenants ... follow a principle of replication ... As God has committed himself to us, so ought we to commit ourselves to each other. The God-human relationship establishes a standard or norm for person-to-person relationships. (pp. 190-191)

The first covenant of importance is God's creation of the relationship between the first man and wife (marriage), together with family relationships. It is important to note here that social existence is not per se a choice, but forms part of the human as an inherent social being (Peters 2014:54). In her discussion of solidarity, Maggay (2017:573-580) makes the following remark about Genesis 2:23:

\footnotetext{
Moreover, some scholars say that Adam here is not so much exercising his duty as name-giver, but as a lover singing and celebrating someone who is, finally, a match for him - he is ish and she is ishshah. The emphasis is on the joyful recognition of similarity, of sameness, of having found a 'soulmate'. Herein lies the mystery of human solidarity, of the sense of corporate identity and the longing for community. As we seek, behold and discover the 'other' in all of her strangeness, we also recognize who we truly are. In acknowledging our shared humanity through all the differences - in gender or in culture - we grow as fit members of a society. (See also Peters 2014:54)
}

This sameness is physical (woman taken out of the man), experience (of a unity), shared humanity (woman taken out of the man) and aims (becoming one directed at forming a family). From the beginning, the human being exists in unity of sameness as each other's helpers (Gn 2:18), who also 
moves outwards in love from their multiplicity and unity and help and support their family (Gn 4). In 17 of the 20 times that the Hebrew word for 'help' (ezer) occurs in the Old Testament, it is used in connection with God. In this first covenant, Eve even mentions that she has brought a child into the world with the help of God (Gn 4:1). The human being as the image of God has to follow this creation covenant. Just like God uses sameness to create solidarity from which help flows, it is the duty of the human being to bring about different kinds of sameness from which help will flow to people in need. It is part of the creation of the human being that as an image bearer he or she will give himself or herself as a gift and help to others.

It is appropriate now, however, to point out that $\sin$ in Genesis 3 afflicted the image bearing of the human being in such a way that there is an unwillingness sometimes to create the structures of solidarity with a view to help other image bearers of God (Clark 2014:67). Maggay (2017:694) refers to the protest of Cain that he sees no reason why he should care about his brother because of their sameness (Gn 4:9).

The second covenant that one can refer to is the covenant with Noah (Gn 6-9). In the grounding of solidarity in the covenant, Clark (2014:63-64) draws the attention to Genesis 9:17: 'God said to Noah: "This is the sign of the covenant that I have established between me and all flesh that is on the earth"'. The Bible reveals that God's covenant with Noah included all living creatures, which also implied all humanity. VanDrunen (2009:31-33) explains it further in his book Bioethics and the Christian life:

Genesis 4:15 and 9:6 are particularly relevant. In both of these texts God ordained a system of human justice not as the sole possession of those who believed in him but as the common possession of the human race. (pp. 31-33; see also Rheeder 2016:10)

Because God is good to all people (Mt 5:44-46; Ps 145:9), the human being has the commission to do good to all people (Gl 6:10), among others to protect their lives. The human being has to promote the common good (Douma 1990:54). Genesis 1-11 is an indication that God will provide earthly authority in the form of universal codes, such as the UDBHR and Article 13, with the purpose of encouraging and even putting the human being under the obligation to promote solidarity among all people (Vorster 2007:108; see also Rheeder 2017).

The third covenant is God's covenant with Abraham and Sarah (Gn 17:4-9). God created a relationship with Abraham and thereby with a homogeneous group, namely the Israelites. God promised his blessing to Abraham and the Israelite people. From this relationship of sameness stemmed the duty of not only receiving blessings but also to be a blessing to people close to you (family), as well as people far from you, namely the whole earth (Gn 12:2-3; Clark 2014:6364; Matz 2017:198).

The fourth covenant of importance is God's covenant with Moses and his people (Ex 19:5-6). God also stepped into a relationship with Moses and his people (sameness), and from that relationship, he brought glory to his people in love because he had saved them from Egypt and established a rule of law (Clark 2014:64). Just like God saved and provided protection, so the people of God (sameness) had to be a 'priestly kingdom' to the world (Ex 19:6; Matz 2017:198). In his sameness with the people of God, Moses followed God in solidarity with the people and as their leader he became part of saving them from Egypt (MacLaren 1991:490).

Fourthly, in his book with the German title Befreiung zur Soldarität: Einfüring in die Evangelische Theologie [An introduction to Protestant theology], Gollwitzer (1982:166) concludes that for the covenantal term hesed, "The most appropriate translation might be "solidarity"' (see also Hungar 1999:111). The word gives expression to the content or the nature of the covenantal relationship between God and his covenantal partners (Ps 103:17-18), as well as between covenantal partners, and it has the meaning of promoting the well-being of the covenantee (Ex 15:13; Ps 6:4, 118:29). From a certain togetherness of marital relations (Gn 20:13; Rt 3:10, Es $2: 9,17)$, family relations (Gn 24:49), friendship relations

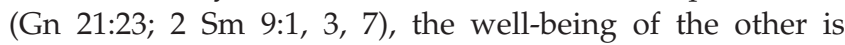
promoted. Gollwitzer (1982:166) summarises the meaning of the covenantal term, saying, '... this is the reason for the making of a covenant ... in order to make possible for him the behavior of chesed, the behavior of true solidarity'.

\section{Christological perspective}

'The starting point of a theology of solidarity is unquestionably the life and work of Jesus Christ' is the view of Peters (2014:51). In his theological perspective on the grounding of solidarity, MacLaren (1991) puts forward in the first place:

Solidarity is centred on following Christ who 'in assuming human nature ... has united to himself all humanity in a supernatural solidarity which makes of it one single family'. (p. 495)

In MacLaren's discussion of Christological solidarity, he uses as his starting point the fact that Christ purposively assumed the human nature and thereby created a sameness with the human being. For Macaleer (2014:31-38), the incarnation of Jesus forms the primary grounding of universal bioethical principles in general and solidarity in particular. It means that all instructions and deeds of Christ regarding vulnerable people have to be understood in the context of this sameness. Christ knows the human nature.

In the second place, the theologian Hans Urs von Balthasar (1990:148-149) is of the opinion that the deepest grounding of the principle of solidarity is found in the doctrine of 'descended into hell' (descendit ad inferos; 1 Pt 3:18-22, 4:6; Mk 3:27). This dogmatic concept as it is found in the Apostles' Creed can be understood in two ways as grounds for the concept of solidarity. The first way is based on a figurative understanding of descending into hell, which refers to Christ's physical suffering, God-forsakenness and rejection on the cross on the Friday. The Biblical grounding for this point of departure is found in the call of anxiety by Christ on 
the cross (Mk 15:34-37; Cahill 2015:239-241). The Heidelberg Catechism (Q/A 44), for example, explains that there is a sameness between Christ and the human being regarding human nature and experience (e.g. the human soul). Flowing from this sameness, Christ died in the place of the human being on the cross to bear the punishment for sin and in that way brought about salvation (Cahill 2015:245). The human being as the image of God must show this self-sacrifice of Christ:

Solidarity implies a self-transformative process in which everyone involved, oppressed and oppressors alike, place themselves in the condition and situation of 'the other' out of love and respect. Solidarity represents a practise of sacrificial love and self-denial by everyone involved. (Magallanes 2011:742)

Balthasar $(1990: 7,49)$ supports the above interpretation, but distinguishes between the events of the cross and descending into hell, thereby suggesting a second way of understanding the latter phrase. According to him, it forms the essence of Christology. On the Holy Saturday, Christ 'descended into hell', which means he was passively obedient to God (as opposed to the crucifixion, when he was actively obedient). The passiveness of Christ is the outstanding feature of the doctrine. On that day, Jesus moved into a situation of extreme passiveness with no possibility of action or communication. Balthasar (1990:148-149) contends: 'In that same way that, upon earth, he was in solidarity with the living, so, in the tomb, he is in solidarity with the dead'. Christ went through the condition of death, the condition of total and complete desolation and darkness to show that the human being could be in such a condition and get through it (Balthasar 1990:168, 172). The sameness regarding death changes the lives of human beings now in the sense that death does not pose fear and anxiety and that there is always hope in the darkest situation. Cahill (2015:246) summarises Von Balthasar's grounding of solidarity as a duty as follows:

The solidarity par excellence is found on Holy Saturday where Christ joined in utter passivity and solidarity with the dead, suffering the forsakenness that humanity was due. Similarly, we who are in a privileged position are to seek to be in solidarity with those who are in the darkest places, those most seemingly forsaken. (p. 246)

According to Barth (1976:774), solidarity means to descend into hell together with other vulnerable people every day.

In the third place, grounded in the incarnation and his descending into hell, Christ calls upon the human being to love God and his neighbour, which is according to Nolan (1976:61) a call to solidarity at its very core. Magallanes (2011:742) supports this core idea:

From a Christian perspective ... solidarity is grounded in the practice and principle of loving our neighbor, which in the biblical narrative is extended to our enemies. (Mt 5:44; Rm 12:14; p. 742)

Between Christ and the believer a bond of love exists that binds believers together as a unity or one body of Christ (Col 2:2). From this sameness of love, the believers are called upon to love others together by searching for and bringing about peace and thus improve the circumstances of people (Col 3:14-15). Peace brings that which is good into the lives of people (Ps 122:6, 8-9; Matz 2017:199). For this reason, Christ places so much emphasis on changing people's circumstances and bringing about peace by means of love (Mt 5:7,9).

In the Old Testament, in the fourth place, there are suggestions of close solidarity, loyalty and preference for what is motivated by a sameness of identity: language, culture, class, ancestors, family, descendants, political and religious denomination (Ex 15:16). Love for your neighbour primarily meant love for the own people and faith group (Lv 19:16-19; MacLaren 1991:490-491; Nolan 1976:60). Clark (2014:64-65) is of the opinion that the parable of the Good Samaritan (Lk 10:27-28) as an appeal for love is a clear call for solidarity, not only with family, friends or the local community, or the nation, but also with the other or the stranger. This is an appeal for universal solidarity. This statement is confirmed by the fact that Jesus calls upon believers to love their enemies (Nolan 1976:60-61). The Good Samaritan gives expression to the image of God, which like God moves outwards and brings about glory. From the sameness of being human and a feeling of empathy, the Samaritan moved out to help the stranger, and the fact that solidarity is practised with enemies indicates that solidarity does not expect anything in return (Nolan 1976:61). At the root of love or solidarity is a feeling of empathy or sympathy (Lk 7:13; MacLaren 1991:491). The basis of solidarity is the emotion that wells up from the innermost of the human being when he or she sees the need of another human being (Lk 10:29-37; Nolan 1976:67).

In my opinion, Nolan (1976:62) goes too far when he says that love and solidarity with the stranger and enemy replaces own or group solidarity. I think that Jesus broadens the call for solidarity and states it as a duty, but that he does not replace group solidarity with universal solidarity. People form close groups and communities that are frequently the first objective of solidarity and give expression to the duty to show first or more solidarity to the own without excluding the other (Gl 6:10; 1 Th 3:12, 5:12).

\section{Pneumatological perspective}

As regards the early Christian community in Acts 2 and 4, Jurgen Moltmann (2012) states the following:

This community is the primal image of all Christian communities, and the origin of the fundamental idea of Christian social doctrine: solidarity. If we ask today about a new culture of solidarity in a world of individualization and globalization, we can begin here. (pp. 3411-3417; Ac 4:32-35)

Magallanes (2011:743) affirms the explanation of Moltmann saying, 'Acts 2:42-47 is a community where solidarity is well presented'. According to Moltmann and Magallanes, the five themes that form part of a pneumatological understanding and grounding of a culture of solidarity are found in the narrative of Acts 2 and 4 . 
First theme: A community of people existed. The community in the narrative was a group of people that had come to faith in Christ and formed the church (Ac 2:44, 47; 4:33). One of the singular characteristics of the community was the diversity of people that had not known each other previously (Ac 2:9-10; Moltmann, 2012:3419).

Second theme: It was acknowledged that in that community of believers there were people that were in a more privileged position because they possessed abundant sustenance such as land, property and food (Ac 2:45, 47; 4:34; Magallanes 2011:743).

Third theme: The community acknowledged unanimity or sameness with regard to cultural activities, experience and aims (Ac 2:44). The Greek word that is used for 'unanimity' has the meaning of 'sameness'. Louw and Nida (1988:589) classify the Greek word for unanimity (epi to auto) in the subdomain, 'Same or Equivalent Kind or Class', and give the following possible meaning: 'pertaining to that which is identical to something - "same"'. Green (2011:458) translates 'unanimity' as 'solidarity', which is according to him, a synonym for 'koinonia' (Ac 2:42). Furthermore, according to Paul, koinonia means 'sameness' or 'solidarity' (1 Cor 1:9-10; Hessel 1979:255). From the second part of verse 44, it can be deduced that the believers acknowledged and experienced community. With reference to the idea of unanimity, it is also found that the whole group of those who believed were of one heart and soul' (Ac 4:32 - NSRV). It means there was a sameness regarding the feeling and thoughts about specific matters (Moltmann 1997:105-106). Believers further acknowledged and experienced sameness (unanimity, one of heart and soul, koinonia) regarding faith in Christ (Ac 2:42; 4:33) and cultural, religious practices (Ac 2:42, 46-47; 4:33).

Fourth theme: Acknowledgement and experience of sameness led to conscious and purposeful actions and help (Green 2011:458). There was an active awareness of vulnerable people that did not have the necessary sustenance such as housing and food and it led to help and alleviating their challenging circumstances (Magallanes 2011:743). Those in a privileged position sold some of their land with a view to improving the living conditions of the vulnerable people (Ac 2:45-46; 4:34). Green (2011:458) shows that Acts 11:27-30 (solidarity with regard to global hunger) indicates that solidarity was not only a national phenomenon, but that it indeed also had a global horizon. According to Moltmann (2012:3411), further motivation to give help is found in the experience of faith in the resurrection from death by Jesus Christ (Ac 4:33). Some people acknowledge that there is only one life and realise that everyone will die. Fear of death sometimes leads to a reaction of avarice where people cannot get enough out of life. Because believers live from the experience that there is an abundant life after death, they do not have to possess everything in this life and therefore they can share their earthly existence with each other.

Fifth theme: There is also a connection between solidarity and health (Moltmann 1997:109-110). The sameness idea is continued in the New Testament with the 'we-are-one-body' image of the church ( $\operatorname{Rm~12:4-5;~} 1$ Cor 12:12-26). It is clear that Paul describes the church as a unity and one body, and the sameness is found in the fact that the church is the body of Christ in Christ. From the sameness, the duty originates to care for weaker members with the gift of healing (1 Cor 12:25, 28). The idea of solidarity is further strengthened by the idea that if one member of the body suffers, all the members suffer together (1 Cor 12:26; Matz 2017:198). Moltmann (2012) links solidarity and health as follows:

It is a counter-image to all the societies with social inequality and want ... The opposite of poverty is not wealth, but community. In community individuals become rich, rich in friends who can be trusted, rich in mutual help, rich in ideas and powers, rich in the energies of solidarity. These energies simply lie fallow or are repressed. All helpful actions have come into being at the grass roots: kindergartens, neighbourhood help, care for the poor and the sick, and other citizens' action groups. (pp. 3435-3443)

In the light of the above theological discussion, one can agree with the conclusion of Matz (2017:134) that '.. justice and solidarity are foundational principles of Protestant social ethics'. Also with regard to the health environment, it can be said the idea of sameness from which help flows to vulnerable people as an expression of human dignity - in short, solidarity flows from the human being as the image of God, the covenant, the descent of Christ into hell, Christian love and the example of the early Christian community. It is clear that Article 13 of the UDBHR can be grounded in a broad Protestant social teaching; therefore, the call for solidarity can be encouraged, wholeheartedly supported and executed.

\section{Conclusion}

In the development and acceptance of Article 13 of the UDBHR, the Protestant faith tradition was not involved in the consultation process (other traditions were indeed consulted). This brings the universality (UNESCO perspective) as well as the acceptability of the declaration and its principles (civic perspective) into question. To address this issue, it is necessary to involve the Protestant tradition in the discourse by presenting own reasons to support the universal principles in the declaration (theological perspective). This discourse has shown that solidarity as a shared value can be grounded in a Trinitarian approach; therefore, the call of the declaration to promote this principle seriously in the field of global bioethics can be supported by the Protestant religious tradition (see also Rheeder 2017).

\section{Acknowledgements Competing interests}

The author declares that he has no financial or personal relationships which may have inappropriately influenced him in writing this article.

\section{References}

Balthasar, H.U.V., 1990, Mysterium Paschale: The mystery of Easter, T\&T Clark, Edinburgh.

Barth, K., 1976, Church dogmatics: Vol. 4, The doctrine of reconciliation: Pt. 1, T\&T Clark, Edinburgh. 
Bridger, F., 1995, 'Equality', in D.J. Atkinson, D. Field, A.F. Holmes \& O. O'Donovan (eds.), New dictionary of Christian ethics \& pastoral theology, pp. 352-353, InterVarsity Press, Downers Grove, IL.

Burton, B., 2002, 'Proposed genetic database on Tongans opposed', BMJ: British Medical Journal 324(7335), 443-443. https://doi.org/10.1136/bmj.324.7335. $443 / a$

Cahill, J., 2015, 'The descent into solidarity', Journal of Reformed Theology 9(3), 237-248. https://doi.org/10.1163/15697312-00903015

Childress, J.F., 2002, 'Protestant perspectives on informed consent: Particularly in research involving human participants', Fordham Urban Law Journal 30, 187-206.

Clark, M., 2014, The vision of Catholic social thought: The virtue of solidarity and the praxis of human rights, Minneapolis Fortress Press, Minneapolis, MN.

Douma, J., 1990, Ethiek en recht, Van den Berg, Kampen.

Elungu, A., 2009, 'Article 13: Solidarity and cooperation', in H. ten Have \& M. Jean (eds.), The UNESCO Universal Declaration on Bioethics and Human Rights: Background, principles and application, pp. 211-217, Ethics series, UNESCO, Paris.

Evers, A. \& Klein, M., 2010, 'Solidarity and care in Germany', in W. Arts, R. Meulen \& R. Muffels (eds.), Solidarity in health and social care in Europe, pp. 160-187, Kluwer Academic Publishers, Dordrecht.

Gallagher, C.M., 2014, 'A Christian consideration of human vulnerability in healthcare and research', in J. Tham, A. Garcia \& G. Miranda (eds.), Religious perspectives on human vulnerability in bioethics, pp. 135-141, Advancing global bioethics: 2, Springer, Dordrecht.

Garrafa, V., 2014, 'Solidarity and cooperation', in H.A.M.J. ten Have \& B. Gordijn (eds.), Handbook of global bioethics, pp. 169-186, Springer Science + Business Media, Dordrecht.

Garrafa, V., 2016, 'Discrimination, ethics of', in H. ten Have (ed.), Encyclopedia of global bioethics, pp. 908-917, Springer International Publishing, Cham.

Gollwitzer, H., 1982, An introduction to Protestant theology, Westminster Press, Philadelphia, PA.

Green, J.B., 2011, 'Koinonia', in J.B. Green, J.E. Lapsley, R. Miles \& A. Verhey (eds.), Dictionary of scripture and ethics, pp. 458-459, Baker Academic, Grand Rapids, Ml.

Gunson, D., 2009, 'Solidarity and the universal declaration on bioethics and human rights', Journal of Medicine \& Philosophy 34(3), 241-260. https://doi.org/10.1093/ jmp/jhp022

Hessel, D., 1979, 'Solidarity ethics: A public focus for the church', Review of Religious Research 20(3), 251-263. https://doi.org/10.2307/3510027

Heyns, J.A., 1982, Teologiese etiek: Vol. 1, N.G. Kerkboekhandel, Pretoria.

Higginson, R.A., 1995, 'Ethics of medical care', in D.J. Atkinson, D. Field, A.F. Holmes \& O. O'Donovan (eds.), New dictionary of Christian ethics \& pastoral theology, pp. 93-99, InterVarsity Press, Downers Grove, IL.

Hollinger, D.P., 2008, Choosing the good: Christian ethics in a complex world, Baker Academic, Grand Rapids, MI.

Hungar, K., 1999, 'Solidarity', in E. Fahlbusch, J. Milic Lochman, J. Mbiti \& J. Pelikan (eds.), The encyclopedia of Christianity, vol. 5, pp. 110-112, Eerdmans, Grand Rapids, MI.

IBC, 2004, Eleventh session [of the] International Bioethics Committee of UNESCO (IBC), UNESCO Headquarters, Paris, pp. 23-24, viewed 04 September 2016, from http://portal.unesco.org/shs/en/files/7495/11103874181ReportCIB11_en.pdf/ ReportCIB11_en.pdf

IBC, 2008, Report of the International Bioethics Committee of UNESCO (IBC) on consent, viewed 04 September 2016, from http://unesdoc.unesco.org/ images/0017/001781/178124e.pdf

IBC, 2010, Report of the International Bioethics Committee of UNESCO (IBC) on socia responsibility and health, viewed 04 September 2016, from http://unesdoc. unesco.org/images/0018/001878/187899E.pdf

IBC, 2015, Report of the IBC on the principle of the sharing of benefits, SHS/YES/IBC 22/15/3 REV. 2, UNESCO, viewed 04 September 2016, from http://unesdoc. unesco.org/images/0023/002332/233230E.pdf

Khoo, S., 2015, 'Solidarity and the encapsulated and divided histories of health and human rights', Laws 4(2), 272-295. https://doi.org/10.3390/laws4020272

Kirby, M., 2009, 'Article 1: Scope', in H. ten Have \& M. Jean (eds.), The UNESCO Universal Declaration on Bioethics and Human Rights: Background, principles and application, pp. 67-80, Ethics series, UNESCO, Paris.

Langlois, A., 2013, Negotiating bioethics: The governance of UNESCO's bioethics programme, Taylor and Francis, London.

Lorenzen, T., 2009, 'Justice anchored in truth: A theological perspective on the nature and implementation of justice', International Journal of Public Theology 3(3), 281-298. https://doi.org/10.1163/156973209X438256

Louw, J. \& Nida, E., 1988, Greek-English Lexicon of the New Testament based on semantic domains, vol. 1, United Bible Societies, New York.

Macaleer, R.D., 2014, The New Testament and bioethics: Theology and basic bioethics principles, Pickwick Publications, Eugene, OR.

MacLaren, D., 1991, 'Solidarity beyond the clichés: A theological perspective', New Blackfriars 72(854), 489-496. https://doi.org/10.1111/j.1741-2005.1991. tb03736.x

Magallanes, H., 2011, 'Solidarity', in J.B. Green, J.E. Lapsley, R. Miles \& A. Verhey (eds.), Dictionary of Scripture and ethics, Baker Academic, Grand Rapids, MI.
Maggay, M.P., 2017, Global kingdom, global people: Living faithfully in a multicultural world, Langham Global Library, Carlisle, England.

Martin, J.F., 2014, 'Privacy and confidentiality', in H.A.M.J. ten Have \& B. Gordijn (eds.), Handbook of global bioethics, pp. 119-137, Springer Science + Business Media, Dordrecht.

Matz, B., 2017, Introducing protestant social ethics: Foundations in scripture, history, and practice, Baker Academic, Grand Rapids, MI.

Moltmann, J., 1997, The source of life: The Holy Spirit and the theology of life, Fortress Press, Minneapolis, MN.

Moltmann, J., 2012, Ethics of hope, Fortress Press, Minneapolis, MN.

Morphew, D., 2015, Kingdom theology and human rights, Derek Morphew Publications, Bergvliet.

Nolan, A., 1976, Jesus before Christianity: The gospel of liberation, David Philip, Cape Town.

Pauls, M. \& Hutchinson, R., 2008, 'Protestant bioethics', in P.A. Singer \& A.M. Viens (eds.), The Cambridge textbook of bioethics, pp. 430-435, Cambridge University Press, Cambridge.

Peters, R.T., 2014, Solidarity ethics: Transformation in a globalized world, Fortress Press, Minneapolis, MN.

Plantinga, R.J., Thompson, T.R. \& Lundberg, M.D., 2010, An introduction to Christian theology, Cambridge University Press, Cambridge.

Prainsack, B. \& Buyx, A., 2011, Solidarity: Reflections on an emerging concept in bioethics, Nuffield Council on Bioethics, London.

Rawls, J., 1993, Political liberalism, Columbia University Press, New York.

Reichlin, M., 2011, 'The role of solidarity in social responsibility for health', Medicine, Health Care and Philosophy: A European Journal 14(4), 365-370. https://doi. org/10.1007/s11019-011-9320-5

Revel, M., 2009, 'Article 12: Respect for cultural diversity and pluralism', in $\mathrm{H}$. ten Have \& M. Jean (eds.), The UNESCO Universal Declaration on Bioethics and Human Rights: Background, principles and application, pp. 199-209, Ethics series, UNESCO Publishing, Paris.

Rheeder, A.L., 2016, 'Global bioethics and human rights in an African context: A reformed theological discourse on global bioethics as a new human rights ethos', In Luce Verbi 50(1), 1-11. https://doi.org/10.4102/ids.v50i1.2080

Rheeder, A.L., 2017, 'Respect for cultural diversity as a global bioethical principle. Own reasons from a Protestant perspective', HTS Teologiese Studies/Theological Studies 73(3), a4705. https://doi.org/10.4102/hts.v73i3.4705

Rusthoven, J.J., 2014, Covenantal biomedical ethics for contemporary medicine: An alternative to principles-based ethics, Wipf \& Stock, Eugene, OR.

Scholz, S., 2016, 'Solidarity', in H. ten Have, (ed.), Encyclopedia of global bioethics, pp. 2652-2658, Springer International Publishing, Cham.

Shickle, D., 2014, 'Biobanking', in H.A.M.J. Ten Have \& B. Gordijn (eds.), Handbook of global bioethics, pp. 485-503, Springer Science + Business Media, Dordrecht.

Stott, J.R.W., McCloughry, R. \& Wyatt, J., 2006, Issues facing Christians today, 4th edn., Fully rev. and updated by Roy McCloughry, with a new chapter by John Wyatt, Zondervan, Grand Rapids, ML.

Taylor, C., 1994, 'Politics of recognition', in A. Gutmann (ed.), Multi-culturalism, pp. 25-75, Princeton University Press, Princeton.

Taylor, C., 2007, A secular age, Belknap Press of Harvard University Press, Cambridge, MA.

Ten Have, H., 2011, Bioethiek zonder grenzen: Mondialisering van gezondheid, ethiek en wetenschap, Valkhof Pers, Antwerpen.

Ten Have, H., 2016, Global bioethics: An introduction, Taylor \& Francis, Milton Park, UK.

Ten Have, H. \& Jean, M., 2009, 'Introduction', in H. ten Have \& M. Jean (eds.), The UNESCO Universal Declaration on Bioethics and Human Rights: Background, principles and application, pp. 17-57, Ethics series, UNESCO, Paris.

Tham, J., 2014, 'Introduction: The principle of vulnerability: Meeting ground of six religions', in J. Tham, A. Garcia \& G. Miranda (eds.), Religious perspectives on human vulnerability in bioethics, pp. 1-7, Advancing global bioethics: 2, Springer, Dordrecht.

UNESCO, 2005, Records of the general conference, 33rd session, Paris, 3-21 October: vol. 1, Resolutions, viewed 11 September 2016, from http://unesdoc.unesco.org/ images/0014/001428/142825e.pdf

UNESCO, 2006, Universal declaration on bioethics and human rights, viewed 11 September 2016, from http://unesdoc.unesco.org/images/0014/001461 /146180e.pdf

UNESCO, 2008, Bioethics core curriculum: Section 1, Syllabus Ethics Education Programme, Sector for Social and Human Sciences, Division of Ethics of Science and Technology, viewed 11 September 2016, from http://unesdoc.unesco.org/ images/0016/001636/163613e.pdf

UNESCO Chair in Bioethics, Haifa, 2016, Casebook on bioethics for judges, Israel National Commission for UNESCO, Jerusalem, viewed 06 February 2017, from http://www.unesco-chair-bioethics.org/?mbt_book=casebook-on-bioethics-forjudges

VanDrunen, D., 2009, Bioethics and the Christian life: A guide to making difficult decisions, Crossway, Wheaton, IL.

Van Leeuwen, E., 2014, 'Protestantism', in H.A.M.J. Ten Have \& B. Gordijn (eds.), Handbook of global bioethics, pp. 419-427, Springer Science + Business Media, Dordrecht. 
Volf, M., 1996, Exclusion and embrace: A theological exploration of identity, otherness, and reconciliation, Abingdon Press, Nashville, TN.

Vorster, J.M., 2004, Ethical perspectives on human rights, Potchefstroom Theological Publications, Potchefstroom.

Vorster, J.M., 2015, Christelike etiek in 'n sekulariserende samelewing, AOSIS, Durbanville.

Vorster, N., 2007, Restoring human dignity in South Africa: Christian anthropology in new dispensation, Potchefstroom Theological Publications, Potchefstroom.
Waldron, J., 2010, 'The image of God: Rights, reason, and order', in J. Witte \& F.S Alexander (eds.), Christianity and human rights: An introduction, pp. 216-235, Cambridge University Press, Cambridge, NY.

Wallace, K.A., 2009, 'Common morality and moral reform', Theoretical Medicine and Bioethics 30(1), 55-68. https://doi.org/10.1007/s11017-009-9096-2

Wenar, L., 2017, 'John Rawls', in E.N. Zalta (ed.), The Stanford encyclopedia of philosophy, Spring edn., viewed 09 October 2017, from https://plato.stanford. edu/archives/spr2017/entries/rawls/ 